\title{
Professional Learning Experience of Pre-service PE Teachers during Teaching Practice 體育阶訓生於學校實習的專業學習經歴
}

\author{
Chung LI \\ Department of Creative Arts and Physical Education \\ The Hong Kong Institute of Education, HONG KONG
}

李 宗

香港敉育學院體藝學系

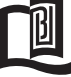

\begin{abstract}
This paper is concerned with a qualitative study of how 15 pre-service PE teachers, who are taking the two-year full-time teacher training course, develop professionally in their second field experience. With the interpretive research paradigm as conceptual framework, data were collected through interviewing and writing of reflective journals. Groups of pre-service PE teachers were found possessing different professional learning experiences concerning their conceptions and socializing strategies. Their professional conceptions included "educating pupils to learn", "seeing PE as catharsis, discipline and having fun". Their socializing strategies composed of finding means to improve teaching, and adopt social tactics for managing pupils and defensive attitude for handling crisis. The study provides an understanding of pre-service PE teachers in the Hong Kong Institute of Education and their learning-to-teach processes. The findings serve as the backdrop for recommending possible pedagogical changes for facilitating desirable professional development of pre-service PE teachers.
\end{abstract}

Keywords: Field experience, physical education teacher education, professional learning

\section{摘 要}

本研究目的是利用詮釋理念, 透過會談及反思報告所搜集的資料, 探討十五位體育師訓學員於第二次學校實習的經歷。研究 結果顯示學員基於不同的意向及經歷而對體育的敉學有著不同的理念, 其中包括視之為促進學生學習、減輕壓力、訓練紀律和獲 取歡樂等工具。他們的職化策略則包括改善教學方法、運用社交手段以管理學生及採取防禦性的態度以應付危機。研究結果有助 加深了解這些準體育教師的專業發展, 期望能對體育師資培訓課程帶來實際的啟示。

\section{Field Experience}

Field experience (FE) has long been identified as an indispensable component of the physical education teacher education programme (PETE). Dodds (1989) explains that FE includes all processes (some deliberate or conscious, others random or unconscious) through which trainees' present teaching perspectives are changed through encountering people and situations in schools...such changes come from a combination of their own agency and that of others, most notably in professional teachertraining programs... (p.82).

Eraut (1994) suggests that FE is very often designed according to the epistemological understanding of the teacher education institutes and schools concerned. These institutions may produce two distinct types of professional knowledge about teaching: "the theoretical / propositional" knowledge and the "craft / practical / process" knowledge. The design of the FE is primarily based on the "theory 
into practice" model and the "integration" principle. The assumption is that the theoretical/ propositional knowledge learnt in the teacher education institutes will automatically be applied by pre-service physical education teachers (recruits) during their practices of teaching in schools.

This study mainly concerned with recruits' 2nd FE titled "the teaching practice" in secondary schools which lasted for eight weeks before graduation. Recruits were expected to learn the complexities of practical teaching, to relate the practice to their PETE programmatic values, and to enhance their teaching independently. Before the 2nd FE, recruits had already taken their first FE in secondary schools scheduled at the end of the 1 st year study. It involved them in a five-week practical teaching experience with the help of the supporting teachers (similar to the terms, mentors used in the UK and cooperating teachers in the US). Recruits had also completed 18 credit-bearing Institute-based modules with essential academic, pedagogical and curricular knowledge and skills of teaching PE. The PETE has been developed from the knowledge of effective teaching with behavioural analysis perspective in teacher education. The perspective places emphasis on the development of observable teaching behaviours related to pupils’ learning (Metzer, 1990).

In the past decade, research findings illustrated that recruits were found experiencing considerable professional learning and development in their FE (Curtner-Smith, 1996; Larson, 2005; Wood et al, 2000). They usually changed their attitudes positively towards teaching children and being teachers (O'Sullivan \& Tsangaridous, 1992; Dodds, 1989). Their perceptions on teaching effectiveness (Paese, 1987) were also shaped affirmatively. Such an experience could enhance their knowledge of PE (CurtnerSmith, 1996), educational ideologies (Templin, 1979) and pedagogical content knowledge (Wood et al, 2000) significantly.

However, some conflicting results concerning the negative impacts were also found among certain recruits (Askin \& Imwold, 1994; Hardy 1995; Wright, 2001). Some of them complained that their FE was not systematic organised and provided them with too little practical teaching experience. Some commented that collaborations between the teacher training institutes and the FE schools were rare. The FE was even criticised for failing to alter their strong impacts of anticipatory socialisation (Lawson, 1983; Allison et al, 1990) and driving the recruits to become more negative, custodial and authoritarian (Templin, 1979).

Schempp (1985) and Placek and Dodds (1988) suggested that if the professional development of recruits was to be facilitated through FE, an understanding of their conceptions and actions was necessary. More studies are needed to focus on the nature and the process that recruits have actually involved in developing their personal conceptions of teaching and how they have managed their professional learning during the FE.

\section{Methodology}

Understanding how the 15 recruits experienced their professional learning in the 2nd FE was the major focus of this study. It is primarily qualitative and the interpretive inquiry was adopted to comprehend how recruits experienced their $\mathrm{FE}$ in holistic and naturalistic manners (Patton, 2002). The central thought of the interpretive inquiry is "hermeneutics" stressing on the importance of understanding and interpretation. It involves the interplay of meanings between the researcher and recruits with the awareness of the context (Bleicher, 1982).

\section{Participants}

12 males and 3 females recruits with the ages between 18 and 25 were purposefully selected. They were divided into 5 categories based on their differences in attitudinal dispositions revealed in their PETE. The sample size ( $40 \%$ of the total population) and the age range were considered as reasonable and representative. During negotiating access, their consent was obtained. They were explained with the details of the study, their rights and obligations. Various pseudonyms in the form of common Chinese surnames and first names were adopted to ensure anonymity and confidentiality of the recruits. Below is the detailed description of each group:

Recruits with an orientation towards "coaching" were the 3 athletes in basketball and athletics (1 female and 2 males with the pseudonyms of Chung, Tao and Lai). As the ex-members of the youth Hong Kong squads, they wanted to prolong their sporting life and continue to enjoy such experiences. For them, being PE teachers was a step to follow their coaches' career path and become elite coaches. 
Recruits with an orientation towards "teaching affinity" were the 2 males and 1 female with the pseudonyms of Fai, Leung and Yan. They had more positive and rich experiences from their secondary school PE. They took their PE teachers as their role models and possessed strong mission of educating pupils through PE.

Three males recruits with the pseudonyms Chan, Man and Kuen had an orientation towards "apprehensiveness". They were less skilful recruits concerning unimpressive physical appearance and weak skill proficiency. They had relatively limited PE involvement in their secondary school years and had a rather low image of themselves.

Recruits with an orientation towards an easy-going style had relatively vague conceptions about PE. They were named Kai, Shing and Ho. These 3 carefree male recruits did not have much expectation on themselves and the subject. Some joined the PETE because they thought that it was easy and comfortable to be PE teachers. Others just accepted what had been offered to them.

Two males and one female recruits possessed an orientation towards "pragmatic considerations" with the pseudonyms, Hang, Tung and Kwan. They had much knowledge concerning the admission, the course requirement, and the career options available. In their mind, joining PETE provided them with better opportunities of getting a job and opened them for other career options like being coaches or recreation officers. It appears that they know much about themselves and see clearly where they are going.

Data were collected through semi-structured interviews and reflective journals immediately after the FE. The interview, which lasted for about 30 to 45 minutes, was versatile and flexible (Byra \& Karp, 2000). The duration was thought to be suitable for collecting all necessary information as well as maintaining recruits' concentration. Samples of the reflective journal and the interview are attached in Appendix 1 and 2 for reference.

Through inductive analysis, all data were transcribed, organised and coded. Emerging and recurring themes concerning recruits' professional learning experiences in the FE were identified for content analysis and compared constantly. During the process, phenomena such as the professional conceptions and socialising strategies of different groups of recruits were interpreted in a wider context of their professional development. They were then interpolated with the data and cross-case analysis in the process of "saturate", "abstract", "conceptualise" and "test" with a spiral and back and forth manner (Strauss \& Corbin, 1998).

"Trustworthiness" and "authenticity" of the data suggested by Guba (1990) were employed to establish credibility and legitimacy of this research. Accordingly, methodological means including direct quotations with the recruits' own wordings were adopted to ensure the depth and authenticity of the data. Translation of the scripts of interviews and reflective journal was undertaken by a PE professional and verified by the recruits. Data of the reflective journals were used for triangulating the accounts made by recruits during the interview to ensure that the transcripts were describing their responses authentically (Denzin, 1989).

\section{Analysis and Discussion}

During the study, recruits were found maintaining different personality types and attitudinal dispositions including orientations towards coaching, apprehensiveness, teaching affinity, pragmatic considerations, and an easygoing style. From the cognitive and behavioural differences, two themes, namely professional conceptions and socializing strategies were emerged.

\section{Professional Conceptions}

Professional conceptions in this study refer to recruits' view about the purpose of $\mathrm{PE}$ and the perceived criteria required for $\mathrm{PE}$ teaching. The recruits with an orientation towards coaching expected that the purpose of PE should be "promoting learning for their pupils". As illustrated in the interview after the second FE, "motivating pupils to learn" and "committing pupils to be involved in their teaching activities" were recalled frequently. In the interview, Tao related such a conception by saying that, "I think a PE teacher should know how to plan interesting activities. Moreover, he should have the capability to motivate pupils to participate...". Lai had a similar opinion and said, "She (the PE teacher) should be good at giving instruction and demonstration. She should know how to convince others to work ...."

The desire of recruits with an orientation towards teaching affinity to do something for the pupils was 
evidenced. During the interview, Leung illustrated his positive conception on PE teaching by saying that, "I understand that teaching $\mathrm{PE}$ needs patience. If we want to help our pupils to make improvement, it takes time." This group of recruits also identified the criteria of skill proficiency (Fai, Leung, Yan), managerial competence for establishing positive learning environment (Fai, Leung, Yan), social competence for maintaining relationships with pupils, PE teachers and tutors (Leung, Yan) and instructional skills (Fai) as important for PE teaching.

Coincidently, all recruits with an orientation towards apprehensiveness were arranged to teach in the schools where pupils' academic and discipline were good. Although they experienced relatively little discipline problem of the pupils, they immediately encountered other problems in motivating pupils to participate and learn. In the interview, they recalled their notable incidents in the form of teaching episodes illustrating the low motivation and passive participation of their pupils in the activities. In the reflective journal, Man articulated:

The pupils seemed to enjoy the first few lessons.

Then they became bored in the following lessons. The situations in the Form three classes were even worse. They stopped working and sat on the mats when I walked to the other side of the gymnasium to give individual supervision...(Man)

Accordingly, they started to establish social relationships with pupils. Comments about friendliness (Chan), sharing and caring (Man), and maintaining dialogues with the pupils (Kuen) were common. They tried to bring "fun" to their lessons. In their mind, bringing fun to their pupils was not only an indicator of success as illustrated in a number of studies (O'Reilly et al, 2001; Garn \& Cothran, 2006), but also an important element to impel pupils to participate actively. "Fun" was regarded as an outcome of their activities and a means to survive in their FE. For them, fun had to be maintained even when learning was being relinquished.

Recruits with an orientation towards pragmatic considerations were found adopting the direct punitive approach in their FE. They expected managerial task competence as the most important work for PE teachers. Kwan perceived that discipline of the pupils should come first. She said in an absolute manner:
'Management comes before teaching'- our Chinese proverb in teaching is always true. Aiming at good discipline is very important for a PE teacher. Besides, there are usually unexpected things happening in a PE lesson. Pupils need discipline training. My belief on this matter becomes stronger and stronger after each FE. (Kwan)

Discipline was not only perceived by them as the means for controlling the pupils, but also an end in itself. They believed that a proper PE lesson could not be run without disciplinary training. Moreover, they feared that losing control of their class might result in their own vulnerability and jeopardise their attainment of the pass grade in the FE and the completion of their teacher education programme.

Recruits with an orientation towards an easy-going style were found easily influenced by the prevailing PE practice in schools where PE was treated as a school subject that offered recreational activities and served the "let off steam" purpose for the pupils. During PE lessons, pupils could be released from the pressure of their "academic" subjects and PE could serve the function of catharsis. The dialogue of Kai below reiterates the "let off steam" purpose of PE for the pupils:

Sometimes, it is meaningless to concentrate on teaching this and learning that. As far as they enjoy themselves in lesson, the 'let off steam' effect can be promoted. Today, pupils get too much pressure from their academic subjects. Why not let them enjoy playing whatever games they like? (Kai)

Concerning their professional conception of the requirements for PE teaching, they realised that the good skill proficiency and a positive learning atmosphere were important factors to impress upon their pupils. Shing was frustrated at not being able to achieve in this aspect. $\mathrm{He}$ said in a desperate voice, "A PE teacher should be allrounded in skill proficiency... No matter how hard I tried, the pupils still did not appreciate my effort but thought that I was not good in skill proficiency." On the other hand, Ho experienced the sensation of being a hero because of his outstanding football skills. He recalled proudly, "Pupils were usually amazed when I demonstrated my football skills. They responded well when I taught them how to play football after school." 
Table 1. Professional Conceptions of Different Groups of Recruits Demonstrated in the Field Experience.

\begin{tabular}{|l|l|}
\hline Recruits with orientations towards & \multicolumn{1}{|c|}{\begin{tabular}{c}
\multicolumn{1}{|c|}{ Professional Conceptions } \\
(Purposes of PE/ requirements for PE teaching)
\end{tabular}} \\
\hline Coaching & $\begin{array}{l}\text {-Motivating pupils to learn. } \\
\text {-Knowing how to plan interesting activities. } \\
\text {-Good at giving instruction and demonstration. }\end{array}$ \\
\hline Teaching affinity & $\begin{array}{l}\text {-Promoting learning } \\
\text {-Skill proficiency } \\
\text {-Managerial competence } \\
\text {-Social competence } \\
\text {-instructional skills }\end{array}$ \\
\hline Apprehensiveness & $\begin{array}{l}\text {-Bringing fun to pupils } \\
\text {-Establishing relationships } \\
\text {-Showing friendliness, sharing and caring attitudes }\end{array}$ \\
\hline Pragmatic considerations & $\begin{array}{l}\text {-PE teaching meant discipline and control } \\
\text {-Managerial task competence }\end{array}$ \\
\hline An easy-going Style & $\begin{array}{l}\text {-Let off steam purpose } \\
\text {-All round and good skill proficiency }\end{array}$ \\
\hline
\end{tabular}

\section{Socializing Strategies}

The second emerging theme, "socializing strategies", refers to the measures and mechanisms that recruits adopted to tackle their professional learning experiences. They might be regarded as modes of professional learning as well as ways that they responded to resolve dissonances.

As revealed in the reflective journal, recruits with an orientation towards coaching experienced serious problems of teaching, including pupils' disruptive behaviours (Chung, Tao, Lai), their failure to motivate pupils (Chung, Lai) and the inadequacy of PE facilities (Chung, Lai). However, they were found to be capable of solving their teaching problems by evaluating their own practices, improving their teaching and impressing pupils with their sports skill competence. Chung, Tao and Lai designed more interesting and challenging activities and tried not to give lengthy instructions in class. Chung had good preparation beforehand and Lai sought comments from the pupils concerning her teaching. In the reflective journal, Chung wrote,

I thought of them (the problems) over and over again. I tried to understand what my pupils thought and needed... I took the pupils' abilities into consideration when writing my lesson plans. I think I gave instruction more clearly and the lessons were better organised afterwards. (Chung)

Besides, they found that excellent demonstration was an effective means to inspire pupils to learn. Their talent could be the envy of the pupils and it helped to establish a better base for learning. In fact, the ability to perform high-level physical skills formed a central aspect of their identity, which revolved around the image of competent sportsperson and able performer. It is a kind of social institution of the "athlete" experienced by the recruits and the pupils. In the interviews, Chung said proudly, "I just showed them a straddle sit and push-up. They were so astonished and told me that they could not do it. Then they all tried hard to practise." Tao recalled eagerly, "I tried my best to demonstrate a triple jump and then I taught them step by step. I discovered that most of the pupils participated wholeheartedly."

Although recruits with an orientation towards teaching affinity experienced similar teaching problems, they inclined towards adopting a humanistic approach (Templin, 1979) in solving them. They tended to accept pupils' own views of their teaching and they had an optimistic view of pupils' discipline. They were found to adopt their socialising strategies in four ways when solving their problems: 
Firstly, their focus on improving teaching acts continued to be a means to solve their dissonance. Secondly, they tended to demand and hold both themselves and their pupils accountable for teaching and learning. Leung recalled that "Pupils have to be held accountable for their learning... The teacher should make the pupils understand his requirement both in and outside of the classrooms." Thirdly, they showed their eagerness to communicate with pupils and seek ideas for improving their teaching. Fourthly, they were found more capable of identifying a wider perspective of the job requirement of a PE teacher. They extended their professional learning through involving themselves in the administrative functions of a PE teacher in their FE schools. Fai and Leung familiarized themselves with the curriculum planning. Fai applied for funding for PE programmes and attended meetings with local PE teachers while Leung and Yan coached sports teams.

In resolving the problems of motivating pupils to participate, recruits with an orientation towards apprehensiveness intentionally relied on their social tactics through showing friendliness, sharing and caring attitude to the pupils. They also thought that they could survive if they maintained dialogue and made compromises with the pupils. Man wrote, "I tried my best to 'maintain a good relationship through talking with them frequently. I also stayed behind after school and played ball games with them." Kuen stated, "I talked to them after the lesson. I sought their opinion on my teaching after school". Eventually, they were relieved and satisfied when their problems were solved partially.

With similar teaching problems, recruits with an orientation towards pragmatic considerations tried to keep their teaching situation under control through establishing their authority and controlling the pupils. In the reflective journal, Hang recorded:

At the beginning of the first lesson, they just went into the PE storeroom and got a football or a basketball. Then they were ready to play on their own. I stopped them at once. I tried to execute my power to start my teaching... It was not easy at all. (Hang)

They also conceived themselves to be "passers by". In the interview, Hang explained, "I was so helpless... However, we understood that we were student teachers only. Naturally, they wouldn't listen to us." Tung, bore a similar grievance, said that, "We, as student teachers, were there for just a few weeks. Why should they (the pupils) listen to a 'passer-by'?"

Besides, they tended to put all the faults on others as their defensive strategy. They blamed their pupils but not themselves for shortcomings. To a certain extent, it reflected their desire to avoid taking responsibility as mentioned in Shaver's (1985) study. This type of recruits seldom mentioned their inadequacy and ineffectiveness. In the interview, Hang amplified his "scapegoat" conception by saying that, "The teachers there...I don't mean to say bad things about them, but I found that they worked half-heartedly. I had to make great effort in order to teach properly."

Recruits with an orientation towards an easygoing style experienced more serious problems including misbehaviour such as fighting (Kai, Ho), speaking foul languages (Kai, Shing), being too active (Kai, Ho), low motivation (Ho, Shing) and paying no attention to them (Ho). They were generally sympathetic to the pupils' misbehaviour. When examining the belief of new PE graduates, this group of recruits expressed exactly the concern over "pushing" pupils too much.

They were adaptive student teachers with good social skills. It is not surprising to see that they could adopt a variety of strategies to please and comply with the pupils. In the interview, Shing recalled, "If they behaved well, they would have more time for playing." Ho said, "We tried to settle the problem by compromise. I told them that I would let them play freely at the last few minutes if they worked at what I taught."

They tactfully made use of and even bribed those "hidden leaders" to help in managing the class. Ho reflected in his reflective journal, "there were some "Big brothers" <hidden leaders> in class. I sometimes asked them to help me to look after the class...I asked for their cooperation and tried to be friendly. I even bought them drinks when they were not so disruptive."

Sometimes, they intentionally ignored and pretended that they had seen nothing concerning pupils' misbehaviours. Ho recorded, "When they (the pupils) used foul language, I pretended not to hear it." Shing wrote, "I did not care much about those girls who sometimes sat aside and chatted with each other." Similar to 
Fernandez-Balboa's (1991) study on the belief, interactive thoughts and action of pre-service PE teachers regarding pupil misbehaviour, this group of recruits did not see themselves as part of the teaching context and attributed the responsibility for misbehaviour to the external factors such as the teachers, the pupils and the FE schools. The summary of the socialising strategies of the five groups of recruits is made as follows:

Table 2. Socializing Strategies Adopted by Different Groups of Recruits Identified in the Field Experience.

\begin{tabular}{|c|c|}
\hline $\begin{aligned} \text { Recruits with } \\
\text { orientations towards }\end{aligned}$ & $\begin{array}{c}\text { Socialising Strategies } \\
\text { (Means of handling dissonance/ professional learning) }\end{array}$ \\
\hline Coaching & $\begin{array}{l}\text {-Evaluating practices } \\
\text {-Improving teaching } \\
\text {-Impressing pupils with sports skill proficiency }\end{array}$ \\
\hline Teaching affinity & $\begin{array}{l}\text {-Adopting humanistic approach } \\
\text {-Improving teaching } \\
\text {-Hold both themselves and their pupils accountable for teaching and } \\
\text { learning } \\
\text {-Involving in the administrative and managerial functions }\end{array}$ \\
\hline Apprehensiveness & $\begin{array}{l}\text {-Adopting social strategies through showing friendliness, sharing and } \\
\text { caring attitude to the pupils } \\
\text {-Maintaining dialogues with pupils } \\
\text {-Complying with the pupils' suggestions }\end{array}$ \\
\hline Pragmatic considerations & $\begin{array}{l}\text {-Establishing authority and control over the pupils } \\
\text {-Treating themselves as if they were passers-by } \\
\text {-Putting the blame on others } \\
\text {-Improving their teaching. }\end{array}$ \\
\hline $\begin{array}{l}\text { An easy-going } \\
\text { Style }\end{array}$ & $\begin{array}{l}\text {-Avoiding pushing pupils too much } \\
\text {-Pleasing and complying with the pupils } \\
\text {-Bribing the hidden leaders } \\
\text {-Ignoring and pretending to see nothing }\end{array}$ \\
\hline
\end{tabular}

\section{Conclusion and Recommendations}

The findings suggest that different groups of recruits developed in distinctive ways with emerging themes of professional conceptions and socialising strategies when encountering their FE. They conceived differently the important components required for PE teaching namely proficiency in sports skill, instructional, social, organisational and managerial task competences.

\section{Professional Conceptions}

It is interesting to note that recruits' professional conceptions concerning the purposes of teaching $\mathrm{PE}$ are various according to their typology. They perceived the purposes of $\mathrm{PE}$ as "promoting learning for pupils" (those with orientations towards teaching affinity and coaching), "bringing fun to pupils" (those with orientations towards coaching and apprehensiveness), "maintaining discipline" (those with an orientation towards pragmatic consideration) and seeing PE as cathartic (those with orientations towards coaching and an easy going style).

The professional conceptions appear to be largely individualistic, personalistic, group specific and context bound rather than professional and collectively oriented. Apparently, the PETE is less effective in inculcating the recruits with distinctive conceptions of schooling and PE teaching. It appears that the recruits, in this study, have demonstrated the power of their agency in constructing their own professional perspectives and development in responding to a variety of social institutions of the FE. It is recommended that PE teacher educators should enhance recruits' chances of formulating their vision and assuming the mission of teaching PE. Thus, the detailed information about the context and the possible purposes of PE in schools should be critically appraised. 


\section{Socialising Strategies}

Each group of the recruits was found to adopt its own strategies for professional enrichment. All of them found different means to improve their teaching and professional learning. The socializing strategies included reflecting on their teaching (recruits with an orientation towards teaching affinity), evaluating for improvement (recruits with orientations towards coaching, teaching affinity, pragmatic considerations and an easy-going style), making demands on both themselves and their pupils in order to promote learning (recruits with an orientation towards teaching affinity), showing off their skill proficiency (recruits with an orientation towards coaching), communicating with pupils (all recruits), and extending their professional learning through experiencing administrative functions (recruits with an orientation towards teaching affinity).

Recruits such as those with orientations towards pragmatic considerations, an easy-going style and apprehensiveness were also found to adopt social tactics for coping, interacting and managing their pupils. These cover "psyching out", conforming to and complying with the requirement of the tutors and PETE, pleasing, reconciling with and bribing the pupils.

Apart from those with an orientation towards teaching affinity, recruits tended to use self-defensive attitudes of finding excuses to protect themselves from destructive anomalies in the sports field. The strategies comprise adopting internal adjustment, "closing their eyes" to pupils' misbehaviour, finding excuses and being "passers-by".

These types of socializing strategies illustrate recruits' active role in dealing with professional learning in the field setting in schools. This demonstrates the recruits' "sub-cultures" have strong impacts on their perspectives and decisions of seeing and solving problems in their dynamic and dialectical FE. This also represents recruits' "studentship" which explains a variety of behaviours that would empower them with choices in their professional learning (Graber, 1991). Although some of the strategies appear to undermine the programmatic messages of the PETE, they ought to be understood in terms of etiology. Thus, it is unfair to simply elicit "blame" on recruits for focusing on the short cuts.
In addition, the programme design of PETE should include the elements of cultivating recruits with critical reflexivity in assessing the causes, actions and consequences concerning problems and strategies during FE. Recruits should be aware of such potential dissonances. They should also be prepared adequately with a variety of coping strategies. Eventually, the goal of enhancing learning and teaching could be achieved.

Besides, a close collaboration between FE schools and the Institute should be supported and closely monitored. Such a "collaborative partnership" can be achieved through formulating clear roles and functions for the Institute, the FE schools, the tutors and supporting teachers.

On the whole, a concerted effort to understand the professional learning of the recruits should be made by teacher educators, researchers and practitioners in the PE field It is only through such an attempt that a more enlightening PETE can be designed and recruits' effective professional learning can be enhanced. In fact, the provision of more contextual relevant preparation experience for our future recruits is crucial. Recruits, then, can progress to become critical, well-informed and competent PE teachers.

\section{References}

Allison, P.C., Pissanos, B.W., \& Sakola, S.P. (1990). Physical Education Revisit-The Institutional biographies of pre-service classroom teachers. Journal of Physical Education, Recreation and Dance. May/June. 76-79.

Askin, J.C., \& Imwold, C.H. (1994). The existence of conflicting perceptions in a secondary PE student teaching experience. Physical Educator. Late winter, $35-46$.

Bleicher, J. (1982). The Hermeneutic imagination, London: Routledge and Kegan and Paul.

Brawdy, P., \& Byra, M. (1995). Supervision of pre-service teachers during early field teaching experience. Physical Educator. Fall, 147-159. 
Byra, M., \& Karp, G.G. (2000). Data collection employed in qualitative research in physical education teacher education. Journal of Teaching in Physical Education. 19, 246-266.

Curtner-Smith, M.D. (1996). The impact of an early field experience on pre-service physical education teachers' conceptions on teaching. Journal of Teaching in Physical Education. 15. 224-250.

Denzin, N.K. (1989). The research act. Englewood Cliffs, New Jersey: Prentice Hall.

Dodds, P. (1989). Trainees, field experiences, and socialisation into teaching. In T.J. Templin \& P.G. Schempp (1989) (Eds.) Socialization into physical education: Learning to teach. WCB Brown \& Benchmark. 81-104.

Eraut, M. (1994). Developing professional knowledge and competence. Great Britain: The Falmer Press.

Fernandez-Balboa, J.M. (1997a). (Ed.). Critical postmodernism in human movement, physical education, and sport. Albany, NY: State University of New York Press.

Garn, A.C., \& Cothran, D.J. (2006). The fun factor in physical education. Journal of Teaching in Physical Education. 25, 281-297.

Graber, K.C. (1991). Studentship in pre-service teacher education: A qualitative study of undergraduates in physical education. Research Quarterly for Exercise and Sport. 62. 41-51.

Guba, E.G. (Ed). (1990). The paradigm dialog. Newbury, CA: Sage.

Hardy, C. A. (1995). Problems in supervision of the practicum. European Physical Education Review, 1(2). 163-172.

Hardy, C. A., \& Mawer, M. (1999). Learning and Teaching in Physical Education. Great Britain: Falmer.

Larson, A. (2005). Pre-service teachers' field experience surprises: Some things never change. Physical Educator. 62(3). 154-163.
Lawson, H. (1983). Towards a model of teacher socialisation in physical education: The subjective warrant, recruitment, and teacher education. Journal of Teaching Physical Education, 2(3), 3-16.

Metzler, M.W.(1990). Instructional Supervision for Physical Education. Champaign, IL: Human Kinetics.

O'Reilly, E, Tompkins, J., \& Gallent, M. (2001). "They ought to enjoy physical activity, you know?": Struggling with fun in Physical Education. Sport, Education and Society, 6(2), 211-221.

O'Sullivan, M., \& Tsangaridou, N. (1992). What undergraduate physical education majors learn during a field experience. Research Quarterly for Exercise and Sport, 63 (4), 381-392.

Paese, P.C. (1987). Analysing the perceptions and teaching effectiveness of pre-service interns. Physical Educator, Fall, 349-354.

Patton, M.Q. (2002). Qualitative research and evaluation methods. Thousand Oaks, CA: Sage Publications.

Placek, J.H., \& Dodd, P. (1988). A critical incident study of pre-service teachers' belief about teaching success and non-success. Research Quarterly, 59(4), 351-358.

Schempp, P. G. (1985). Becoming a better teacher: An analysis of the student teaching experience. Journal of Teaching in Physical Education, 4, 158-166.

Shaver, K.G. (1985). The attribution of blame: Causality, responsibility and blame-worthiness. New York: Springer-Verlag.

Strauss, A. L., \& Corbin, J. (1998) Basics of Qualitative Research. Techniques and procedures for developing Grounded Theory, Thousand Oaks, CA: Sage Publications.

Templin, T. J.(1979). Occupational socialization and the physical education student teacher. Research Quarterly, 50, 482-493.

Wright, S. (2001). The socialisation of Singaporean Physical Educators. Journal of Teaching in Physical Education, 20, 207-226. 


\title{
Appendix 1. The Sample of the Interview Guide.
}

To find out background information of the teaching practice.

To ask for happy and successful experience, unsuccessful experiences?

To explore participants' feeling about the FE?

To go through self-evaluation of the participants by asking:?

-What do you get from the FE?

-What were the difficulties found during the FE?

-What were your strengths?

-What were your weaknesses?

-Did you receive any support from the School PE teacher? Give Comments.

-What are differences in expectation from the pupils through PE before and after FE?

-What do you learn from the FE?

\section{Appendix 2. The Sample of the Reflective Journal.}

Describe the incident(s) that you had encountered with difficulties, frustration or

unhappiness during the FE

How did you deal with it (them)? (Please describe the course of actions).

What were the results and consequences?

How did you feel?

\section{Correspondence:}

\author{
LI Chung \\ Department of Creative Arts and Physical Education \\ 10 Lo Ping Road, \\ Tai Po, NT, Hong Kong. \\ Email: cli@ied.edu.hk
}

